\title{
Changes in Chinese-Indonesian Identity: Indonesianization or Re- Sinicization?
}

\author{
Harryanto Aryodiguno \\ Ph.D. Candidate in International Relations \\ National Taiwan University, Department of Political Science \\ Harryanto@president.ac.id
}

\begin{abstract}
ABSTRAK
Memburuknya hubungan Indonesia dan China pada era Suharto, terutama di Tahun 1965 telah menyebabkan berbagai kerusuhan anti-Tionghoa di Indonesia, yang berakhir dengan membatasi dan mengontrol budaya Tionghoa Indonesia, kemudian dilanjutkan dengan menerapkan kebijakan asimilasi terhadap etnis Tionghoa. Namun, meskipun dengan adanya kebijakan asimilasi, kerusuhan terhadap etnis Tionghoa tetap terjadi, ini dikarenakan adanya anggapan etnis Tionghoa mempunyai status ekonomi yang lebih tinggi, dan mereka juga salah satu penyebab munculnya krisis ekonomi di tahun 1997, yang kemudian puncaknya menyebabkan kerusuhan anti Tionghoa di tahun 1998. Kerusuhan Mei selain mengakhiri rejim Suharto, juga membawa keterbukaan pada masyarakat Indonesia, seiring dengan demokratisasi di Indonesia, orang Tionghoa di Indonesia juga mulai bebas mengekspresikan budaya dan jatidiri mereka. Karena proses demokratisasi di Indonesia beriringan dengan bangkitnya China sebagai kekuatan ekonomi Indonesia. Akankah Tionghoa Indonesia menjalin hubungan yang mesra lagi dengan negeri "leluhur" China? Apakah mereka akan mengidentifikasi diri mereka kembali menjadi orang "Cina" lagi? Tulisan ini memberikan kesimpulan bahwa meskipun China telah bangkit menjadi kekuatan ekonomi dunia, dan Indonesia telah menuju ke arah yang lebih terbuka dan demokrasi, orang Tionghoa di Indonesia tetap mengakui dan lebih memilih menjadi orang Indonesia, hanya saja dalam pandangan budaya, mereka terbagi dua kelompok: kelompok pertama yang merasa lebih Indonesia dari yang lainnya atau yang lebih memilih menjaga jarak dengan China, sedangkan kelompok kedua lebih memilih mengekspresikan budaya Tionghoa dan menjaga hubungan yang lebih erat dengan China.
\end{abstract}

Kata kunci: Tionghoa-Indonesia, Masalah Cina, Kerusuhan Anti-Tionghoa, Suku dan Identitas Nasional, Pencinaan kembali.

\footnotetext{
ABSTRACT

During the Suharto era, which began after the anti-Chinese riots in 1965 as a result of the deterioration of the relation between Indonesia and China, forced policies of assimilation was adopted for curtailing the Chinese culture and to control Chinese-Indonesians. Yet, anti-Chinese sentiments remained, and attacks against them reached its climax in May 1998, when anti-Chinese riots recurred because of the allegation that Chinese-Indonesians had an advantageous
} 
economic status, and they were the culprit that brought financial crisis to Indonesia. The May 1998 riot ended Suharto's era, and Chinese Indonesians saw improvement in their position and condition. Now, they strive to find their own identity and political status. Their efforts to do so were also influence by the rise of China. That is why, this paper aims at examining whether the reintroduction of Chinese cultural celebrations into Chinese-Indonesian community would result in the demise of policies of assimilation. It also examines whether the rise of China would propel them to establish a closer identification with the People's Republic of China. How do Chinese-Indonesians view their identity? How do they choose this identity and their political inclinations? These are the research questions this paper is going to answer. The findings show that the status of the Chinese in Indonesia is divided into two groups. The first group is the one who is determined to break away from Chinese identification, and the second group is the one that still maintains their Chinese culture.

Keywords: Chinese-Indonesians, the "Chinese" problem, Anti-Chinese riots, Ethnic and National Identity, Re-Sinicization

\section{Introduction}

The massive riots taking place in May 1998 in Indonesia have brought many changes to the Indonesian society. The May 1998 violence led to the fall of Indonesia's dictator, President Suharto, and the democratization of Indonesia. One impact of the democratization is the institutional reform, known in Indonesia as "Reformasi," that saw the decline of the anti-Chinese sentiments. This decline was partly because of the international support that condemned the riots attacked Chinese Indonesians, and partly because of the changing perception towards them, as Sarah Turner writes, "Since 1999, there has been an increasing official and general acknowledgement within Indonesian that the ethnic Chinese community received gross injustices during the period of the riot" (2003:347). Chinese Indonesians began to express their ethnicity. They also had the courage to voice their political views. This was also reinforced by the growth of political parties organized by Chinese-Indonesians, along with the proliferation of new political parties in Post-Suharto era. The Chinese-organized political parties are, among others, Partai Reformasi Tionghoa Indonesia abbreviated as Parti (Chinese Indonesian Reform Party) and Partai Pembauran Indonesia, abbreviated as Parpindo (Indonesian Assimilation Party). There have also been a number of media and scholars organizing conferences and seminars for discussing the issues concerning the problem Chinese Indonesians face. Generally, most people think that the "Chinese problem" in Indonesia has been resolved, as seen in the growth of newspapers, radio, and TV programs in Chinese language. But, is that true?

The so-called Chinese problem should be seen within the demographic context of Indonesia. Indonesia is the largest country in Southeast Asia, consisting of thousands of islands. According to the Coordinating Ministry for Maritime Affairs, 
the Deputy of Maritime Sovereignty (Deputi Kedaulatan Maritim, Kementerian Koordinator Bidang Kemaritiman), the territory of the Republic of Indonesia is from "Sabang" to "Merauke," which consists of approximately 17,504 islands. Of which 16,056 islands have passed the UN check (Prasetya, 2018). Besides having many islands and abundant resources, the statistical data from the National Central Bureau of Statistics of Indonesia shows that Indonesia has large population. Indonesia's total population was approximately $237,641,326$ in 2010 , and it increases by $1.49 \%$ annually. The data also shows that the Javanese is the largest ethnic group. It is $40.22 \%$ of the total population. The data for the population of the Chinese varies. The statistical data from the National Central Bureau of Statistics of Indonesia mentions that the total population of the Chinese is $2,832,510$. According to the research data from non-profit foreign organizations, the actual population of Chinese-Indonesian is about 11 million (Christian, 2017.) Conforming to the Overseas Chinese Affairs Council of the Republic of China (Taiwan), Indonesia's Chinese population is approximately 12 to 15 million (Overseas Community Affairs Council, Republic of China "Taiwan" 2016).

Based on the above statistical data, although the number of the Chinese population varies, it shows that Chinese Indonesians belong to ethnic minorities in Indonesia. As a minority, "Chinese problem" in Indonesia, or "Masalah Cina" in the Indonesian vocabulary has attracted the attention from the scholars. Although the Chinese are as few as the other two ethnic groups (India and Arab), there were frequent occurrences of serious anti-Chinese riots before and after Indonesia's independence. Why did Chinese people in Indonesia often become the targets of the riots? Did indigenous Indonesians and Chinese Indonesians have the so-called "original sin" and "original hatred"? In this article, I will explore the identity of the Chinese-Indonesian and after several incidents of Chinese exclusion, what kind of Chinese identity and political inclination are formed?

\section{The History of Anti-Chinese in Indonesia and the awareness of Chinese-Indonesians Identity}

The history of pre-independence and post-independence of Indonesia witness a number of anti-Chinese riots. For example, anti-Chinese riots occurred in Dutch East Indies era, on October 9-11, 1740. The Chinese rebelled against the Dutch East Indies colonial government. This confrontation was considered to be the first "Genocide" in the history of Indonesia. About 10,000 ethnic Chinese were slaughtered, and their bodies were thrown directly into the gutter of the city of Batavia, turning the whole gutter into blood red, so this incident was also called "Tragedy of the Red Gutter" (Peristiwa Angke). ${ }^{1}$ The unrest started when the

\footnotetext{
${ }^{1}$ Angke is a Hokkian (a local Mandarin dialect) language which means "red gutter", in 1740 the colonial government carried out ethnic cleansing of Chinese. More than 10,000 Chinese in Batavia and 60,000 Chinese at outside Batavia were killed. Their blood flows and makes red in the river around it. Since then, the river is called "kali Angke"/red gutter.
} 
Dutch East Indies Governor Adrian Valckenier (1737-1741) continued to accept Chinese immigrants from Fujian province. In the early days, it accepted welleducated overseas Chinese. However, many criminals who committed crimes in China also subsequently immigrated to the Dutch East Indies. Many immigrants entered Dutch East Indies, but there was a lack of job opportunities, thereby creating conflicts between overseas Chinese and the colonial government. On October 4, 1740, 50 Europeans died in Batavia because of these conflicts. As a result, the Dutch East Indies colonial government began to kill the rebellious Chinese. Most of the overseas Chinese fled across the cities of Java. In Mataram, they were protected by the Sultan of Mataram, and then they collaborated to declare war against the Dutch colonial government (Windoro, et. al, 2016). The war was often considered by Indonesian scholars to be the first time Chinese and Indonesians cooperated against the Dutch imperialism. This incident showed that the Chinese had contributed to Indonesia even before it was established. However, why is Chinese "loyalty" still questioned? An economic explanation proposes the Chinese as being "economic animals" and will only make money but neglect local society and unpatriotic to Indonesia. Scholars and Indonesian officials also believe that the Chinese problem is "ethnic and national identity recognition." In regards to "national identity," the question is whether Indonesian Chinese are unwilling to integrate in Indonesian society or disassociate themselves from their Chinese identity, or are Indonesian natives unaccepting of Chinese-Indonesians (Interview with Dr. Sunardi Mulia, 24-25 November 2015).

To understand this problem, I will trace to the different class of society during Dutch rule in the Dutch East Indies by collecting research data from ChineseIndonesian scholars, news in the mass media, and in-depth interviews with Indonesian Chinese scholars. The Chinese formerly were separated from the two racial groups, namely, the Dutch or European Class and the indigenous Indonesians or inlander. The Chinese minority at that time were not classified as "Peranakan" or "Totok."2 In the colonial era, the rise of Chinese nationalism was

\footnotetext{
2 The terms "Peranakan" and "Totok" are straightforward. Peranakans at first depict Chinese people born in Indonesia, both those born from mixed marriages between Chinese and Indonesian people, as well as between Chinese and Chinese people born in Indonesia. While "Totok or Sing Keh ( 新客 ) " are those who have just come from China, and cannot speak local languages, such as Malay. Totok also doesn't understand the local culture. During the Dutch East Indies, there were no striking differences between "Peranakan" and "Totok." It was only after the Dutch East Indies government gave the indigenous and Chinese people the opportunity to get the right to education, the status of "Peranakan "and "Totok" became sticky again. Peranakans are synonymous with a good education or who take western education, while "Totoks" themselves prefer to attend school education based on the culture of Confucianism. The next reality is that "Peranakans" prefer to use local Malay language rather than Chinese language or dialect, while "Totok" still use Chinese dialects, such as Hakka, Hokkien, Tio Ciu, etc. In culture, there is not much difference, the "Peranakans" and "Totok" both still practice Chinese culture, especially those who are still Confucian. After Indonesia's independence, actually there was no more difference between "Peranakan" and "Totok" because they were all born in Indonesia. But among the Chinese themselves, they divided the "Peranakans" and "Totok" by the way that "Peranakans" were those who could not speak the Chinese dialect and had abandoned Chinese culture, and "Totok" were those who still used Chinese-Mandarin and Chinese dialects and practiced Chinese culture. This difference between "Peranakan" and "Totok" only occurs in Java, while the islands of Kalimantan and other islands have no difference between "Peranakan" and "Totok." Chinese people in Kalimantan, for example, would call themselves "Tang Ren" (Chinese people who are still of
} 
intimately connected with the spread of Chinese nationalism in China. Political identification with China, however, emerged clearly after the establishment of the Republic of China in 1912. The ethnic-Chinese felt that the colonial government considered their culture, customs, and ethnicity as the bottom class, so they united to establish the Chinese Association or Tiong Hoa Hwee Koan (Wertheim and The Siauw Giap, 1962).

The first group tends to identify themselves with China and believe that they are always Chinese and must remain loyal to the motherland. This group established the "Tiong Hoa Hwee Koan" on March 17, 1901, and is often referred to as "Sin Po group." The founder of the Tiong Hoa Hwee Koan believed that Chinese Confucianism was critical to Chinese residents in the colonial land. Therefore, they advocated the conveyance of Chinese culture education. However, it was Sin Po, a Peranakan daily newspaper, that spread information related to the Chinese nationalist movement. It also strengthened the political loyalty of the Chinese in Dutch East Indies to the home country. During the Sino-Japanese war, the Chinese in Dutch East Indies launched donations to support the anti-Japanese movement in China (Gu, 2017). Although the primary purpose of Sin Po was to spread Chinese culture in the Dutch East Indies and to support Chinese nationalism, this newspaper was also the first newspaper to use the term "Indonesia" for referring to "Dutch East Indies," and it was the first newspaper that used Malay language. In 1964, because the newspaper supported Sukarno and opposed the anticommunist media when Sukarno was overturned, the newspaper suffered closure (Sudibyo, 2001).

The second group consisted of Dutch-educated and wealthy Chinese who were in favor of Dutch nationality. One of their representatives, Kwe Tek Hoay, believed that the Chinese should participate actively in the Volksraad (people's representative of the colonial government). Even though the Indies Chinese were the citizens of China, they must accept the reality that they lived in the Dutch territory, and they must comply with the law of Dutch East Indian citizens (Wet op het Nederlandsche Onderdaanschap) (Suryadinata, 1994).

The third faction was the Indonesia-oriented group. Indonesia, in their view, Indonesia is their homeland and country of the Indies Chinese. However, their identity remained Chinese. This group was led by Liem Koen Hian and Kwe Kwat Tiong, who established the Indonesian Chinese Party (PTI) in East Java on September 25, 1932. In contrast, one of the members of the Indonesian Independent Review Committee (BPUPKI)--established during the Japanese occupation of Indonesia, Oei Tjong Hauw insisted that after Indonesian independence the Chinese should remain a Chinese citizen. Anyhow, Liem Koen Hian objected, and his reason was that they were born, lived, and died in Indonesia. Therefore, Chinese should also have a standard position with 
Indonesian natives (Jahja, 1995). The contribution of PTI does not mean that the Indonesian natives can genuinely accept Chinese Indonesian. Though the purpose of this party was to work together with Indonesian national activists for Indonesian independence and indeed to contribute to Indonesia's independence, Suharto completely denied the contribution of the Chinese to the Indonesian nation after he took office.

When the Second World War ended, the Chinese who recognized the identity of the Chinese nation established the "Persatuan Tionghoa" (The Chinese Unity) organization in 1948. Later, it was changed into "Partai Demokrat Tionghoa Indonesia" (Chinese Democratic Party of Indonesia) in 1950. The purpose was to preserve the Chinese culture and identity. In the end, it was changed into "Baperki"3 (Indonesian Citizenship Consultative Body) in 1954 (Suryadinata, 2005). After the independence of Indonesia, the Chinese identity was categorized into two types; the first one was a cultural and political orientation toward China, an orientation that maintained Chinese identity, and the other one was an orientation toward Indonesia without alienating itself from its ethnic identity.

Although the political ideology and identity of the two groups were different, most of the Chinese chose to study in Chinese education. In general, the Chinese who chose to study in Chinese schools were relatively close to the Chinese consciousness (regardless of pro-Beijing or pro-Taipei affiliations). On the contrary, the Chinese who chose to study in the English school or a Dutch school was more pro-Indonesian (Interview with Professor Dr. Leo Suryadinata, 4-5 December 2007). The "Baperki" actively played a role in the multiculturalism of Chinese in Indonesia. Then, there was another Chinese organization supported by the Indonesian Army, the Lembaga Pembina Kesatuan Bangsa (Institute for the Development of National Unity, LPKB). The former favored a multicultural policy, emphasizing that the Chinese were a part of the Indonesian nation, while the latter fully supported the separation of Chinese identity and total assimilation. The struggle between the two Chinese organizations ended on September 30, 1965. Following the failure of the coup by the Indonesian Communist Party, Baperki was suspected of supporting the Indonesian Communist Party, and it was banned by the New Order government (Interview with Dr. Thung Ju-Lan, 24 August 2016).

After the September 30 incident $^{4}$ broke out in 1965, the anti-China and antiChinese sentiments started to appear. In particular, after the Army controlled the media, unbalanced news often appeared. Anti-China campaigns continued to

\footnotetext{
${ }^{3}$ Badan Permusjawaratan Kewarganegaraan Indonesia (Baperki) was an organization founded in Indonesia in 1954 by Indonesian of Chinese descent. The organization sponsored schools including Res Publica University (1960). The group was associated with the Indonesian Communist Party (PKI). After the 1965 coup attempt in Indonesia, Res publica was burned down and replaced by a new school, Trisakti, and this group was banned. (Setiono, 2003)

${ }^{4}$ On the evening of September 30, 1965, known as the 30 September movement, six of Indonesia's top military Generals were captured and executed by the group of militants. The movement proclaimed itself as Sukarno's protectors, issuing a preemptive strike to prevent a possible coup by the "anti-Sukarno", pro-Western council of Generals. ( Interview with Professor Dr. Leo Suryadinata)
} 
occur, including incidents such as rushing into Chinese embassies, and burning Chinese stores and houses. Both Baperki and LPKB wanted to integrate the Chinese into the larger Indonesian society. However, the first disappeared after Sukarno lost power. The latter was supported by the Indonesian military and actively participated in the anti-communist movement. Although LPKB wanted to show its loyalty to the Indonesian government, they also actively protested against Baperki. Some of these Chinese, such as the Catholic Party Secretary Harry Tjan Silalahi, also played an essential role in the "KAP-Gestapu" (AntiCommunist groups). He and Soe Hok Gie from the Faculty of Art at the University of Indonesia, and the Catholic University Student Association led by Liem Bim Koen (also known as Sofjan Wanandi) organized the Indonesian Students Action Forum (KAMI) against the Communist and Sukarno regimes (Coppel, 1994).

In order to eliminate the Communist Party and to start the anti-China movement, Suharto's new order regime announced that the People's Republic of China interfered with Indonesia's internal affairs and supported Indonesia's leftist coup. The rumors of China's support for the Indonesian Communist Party's coup d'état eventually led to long-term harm to Chinese Indonesia. The September 30 Incident profoundly affected Indonesian mainstream society's understanding of China and Chinese Indonesians. After the incident, Indonesia's internal affairs and foreign policy restricted local people's understanding of China and Chinese. Although the New Order Government was anti-China, it also recognized that the role of Chinese Indonesians in the economy was vital. If it were to overthrow the Chinese economy, it would be tantamount to overthrowing the country's economy. Under this consideration, the government believed that it was necessary to use the strength of the Chinese to assist the government in building the entire national economy. Therefore, the new order regime adopted two kinds of measures for the Chinese Indonesian in political economy. On one hand, it tried its best to use Chinese's economic prowess in constructing the country. On the other hand, it adopted the monopoly policy that restricted the economic activities of the Chinese, so that Indonesian people could slowly catch up and even replace the role of Chinese Indonesians in Indonesian economy. The New Order regime upheld Indonesianism and hoped that one day Indonesia's indigenous people would replace the Chinese's role in economy and allow the New Order Bureaucracy to get the highest profits. This kind of situation suppresses the Chinese people. If an economic crisis occurs in Indonesia, the Chinese will be accused of being the primary source of economic problems. The anti-Chinese riots may occur at any time (Lai Jian Wen, 2016).

Before the Asian financial turmoil in 1997, most Indonesians had been dissatisfied with the domestic economic performance. Most of them who were dissatisfied with the Chinese Indonesians had already staged anti-Chinese riots in the early 1990s, including Medan in 1994, Tasikmalaya in 1996, and Jakarta in 1997 (Schwarz, 1997). The monetary crisis of 1997 caused massive anti-Chinese riots. All these events triggered the Chinese in Indonesia to question their identity status and 
forced them to make choices. Did they leave Indonesia or continue to become Indonesian? In February 1998, demonstrations led by students from University of Indonesia demanded that the government solve "corruption, collusion between government and business, and nepotism" (known in Indonesian as Korupsi, Kolusi dan Nepotisme), eliminate the dual functions of the military (Dwifungsi $A B R I$ ) and force President Suharto to step down. Clashes between students and police/soldiers on May 12, 1998 resulted in the death of four Trisakti University students. This incident spread into a massive riot against the ethnic Chinese.

The "May Riot" was considered as the biggest anti-Chinese riot in independent Indonesia. Anti-communism and anti-Chinese riots in 1965 were not the one directly targeting the Chinese. Those riots affected not only the Chinese, but other ethnic groups as well. In contrast, the riots in 1998 were purely against the Chinese in Indonesia. Besides that, because China's state property in Indonesia was not affected, Beijing reacted with indifference. Contrary to the active protest in 1965, this time China even shut down the information about the anti-Chinese demonstration in Indonesia.

The main reason why Indonesia often has an anti-Chinese expulsion movement is that the gap between the rich and the poor is enormous. Whenever there is a regime change in Indonesia, the Chinese often become the victims of the political instability. Many Chinese Indonesians do not speak Chinese, and most of them have been separated from Chinese culture. However, each time there is antiChinese protest, Chinese Indonesians are made to rethink their own identity. The targets of anti-Chinese riots in 1998 were all Chinese in Indonesia, regardless of their political orientation whether they were pro-assimilation or pro-China, and of their country of origin whether they were from mainland China or Taiwan. Habibie, who replaced Suharto after the riots, began to change the policies regarding Chinese Indonesians. He believed that Indonesia should learn from historical experiences. He abolished rules and regulations that were discriminative against Chinese, such as laws requiring Chinese-Indonesians to have certificate of Indonesian citizenship (known as Surat Bukti Kewarganegaraan Indonesia or SKBRI), barring the Chinese from participating in politics, celebrating Chinese cultural festivals or banning the use of Chinese language. Indonesia's next President Abdurrahman Wahid continued this policy.

Although many discriminatory regulations and laws have been abolished, it does not mean that discrimination against the Chinese in Indonesia was automatically resolved. Observers take the example of gubernatorial election in the Special Capital Region of Jakarta. In the election, Basuki Tjahaja Purnama or Ahok, the incumbent who wanted to get reelected, was hit by a series of black campaigns. According to Sri Yuniarti, a senior researcher of Indonesian Institute of Sciences, the opponents used identity and religious issues to attack Ahok, such as, Ahok's unsuitability to be the governor because of his Chinese ethnic background and Ahok's depiction as the one who insulted Islam, which was unfounded she said that the election campaign in Jakarta was "unhealthy" because it exploited identity 
politics and capitalized on religious issues in order to get political gain. She particularly mentioned that the mobilization of Muslim militant group to Jakarta created an atmosphere of intimidation and that the use of religious threat, such as, Muslims who voted for Non-Muslim Ahok, would not get a proper religious burial when they died, was clearly blatant use of hate speech (Suryowati, 2017). The Jakarta gubernatorial election clearly shows that although Indonesia claims that it is a multicultural and multi-racial country, its society is still divided into the insider and the outsider. In the Indonesian context, the outsider refers to Indonesians of Chinese background, like the case of the latest Jakarta gubernatorial election. Even though the one who won the election was an Indonesian of Arab ethnic background, many Chinese Indonesians believe that they have not been fully accepted as part of Indonesian nation yet. Their belief is also supported by the fact that most of Indonesia's indigenous ethnic groups still regard their ethnic Chinese counterparts as foreigners.

\section{Anti-Chinese riots and the political cultural tendencies of Indonesian Chinese}

The May 1998 incident, Indonesia's so-called "Black May Riot," shocked and awoke Chinese Indonesians. They become the target of racial riots easily. On May 13, 2013, a television station in United of States, NTDTV Chinese 3, aired its review on the May 1998 incident. It said that Chinese Indonesians were subject to ill treatment and organized killing. According to a statistical source, there were tens of thousands of Chinese who were dead and wounded, and tens of thousands of women were sexually molested and raped. Instead of condemning the riot, Beijing issued a statement that they would not interfere in Indonesia's internal affairs (NTDTVChinese3, 2013). Why are Chinese-Indonesians not protected by Indonesia or China? Some parts of Indonesian authority and society always believe that their Chinese counterparts have no contribution to the local economy. They are economic animal who will return to the "homeland" one day. What kind of views, feelings, or understandings do Chinese Indonesian have about China the "homeland"?

From a historical perspective, before the independence of Indonesia in 1945, the Dutch colonial government had established formal diplomatic relations with the Republic of China and established consulates in various parts of the Dutch East Indies. This consulate existed until Indonesian independence, but it only lasted until 1949 (Gu, 2002). Since the establishment of diplomatic relations with the People's Republic of China (PRC) in April 1950, and Indonesia's recognition of People's Republic of China (PRC) is the legitimate government of China, a lot of laws and regulations detrimental to the pro-Kuomintang or Taiwan. An example is that the Chinese in Indonesia must choose to become Indonesian citizens or become Chinese (PRC) citizens. Those who continued to be pro-Kuomintang and hence to be the citizens of the Republic of China (Taiwan, ROC) were automatically 
become stateless (Qiu, 1995). This is actually the source of the "stateless" Chinese in Indonesia, and the issuance of such laws was seen as the beginning of the discrimination against the Chinese during the Sukarno regime. From a historical point of view, because of the struggle between the Kuomintang and the Communist Party in China, Sukarno made many hostile policies towards the Chinese in Indonesia. According to Qiu Zheng Ou, an overseas Chinese researcher from Taiwan National Defense, at the time when the Chinese in Indonesia had to choose which nationality they wanted, they had two choices: they could choose the nationality of either the Republic of Indonesia or the People's Republic of China. Those who chose to be the nationality of the Republic of China or Taiwan became stateless. So, at that time, each local government in Indonesia, from the provincial to the district level, would have a demographic profile similar to that of the region. The regional government categorized the people living in the region into four, namely, Indonesian indigenous people (Pribumi), Indonesian citizens of Chinese descent, foreign nationals, and stateless people. This classification has been used in various local governments in Indonesia since the Sukarno period until the Suharto era (Qiu, 1965). From a cultural point of view, Chinese Indonesians can be divided into two groups: the "Peranakan" who uses Indonesian or other Indonesian dialects in their daily life habits, and the "new guests" (or "Totok" in the Indonesian language) who still maintain Chinese customs and use the Chinese language in their daily lives. Although many Chinese faced unequal treatment at that time, and laws that were disadvantageous to them began to appear, Chinese Indonesians wanted to integrate into Indonesian society. At that time, there were two different views; the first one was that the Chinese who integrated into Indonesian society did not have to separate themselves from their Chinese culture and hence retain their Chinese identity. This group was called "integrationist". The second one preferred a complete disengagement from Chinese culture and recommended assimilation, and hence was called "assimilationist". As mentioned above, the struggle between the two groups ended on September 30, 1965. After the Indonesian Communist Party launched a coup d'état, Indonesia's newly appointed military regime banned the activities of the "integrationists" and monitored its leaders (Interview with Dr. Thung Ju Lan, 24 August 2016).

After 1965, on the pretext of anti-communism, the word "China" became problematic. Between 1966 and 1968, anti-China movements occurred in Jakarta every day. The assimilationist Chinese actively participated in the anti-Communist movement. This group, "the rightist" protested against "their own people" and demanded that Sukarno immediately cut off diplomatic relations with China, and even supported the government's closure of the Chinese school. They claimed to be Indonesians. In so doing, they hoped that they would not be foreigners because they were always regarded as China's spokesmen in Indonesia (Kompas, 1966). Therefore, the anti-China sentiment was on the rise at that time. The Chinese in Indonesia were under high pressure. They must state their allegiance to Indonesia, by abandoning their own culture and identity. 
After Suharto assumed office, the political situation was relatively stable. In the early 1970s, most of the Chinese had no contact with relatives and friends in mainland China or Taiwan. According to Liao Zuolian, an "old overseas Chinese" living in Indonesia, in the 1970s, their contacts with "Chinese mainland" friends or relatives were helped by "third parties." ${ }^{5}$ At the same time, if they want to know about "China," "Taiwan," or the news of the Chinese community, they will read magazines, videotapes, etc. that have been secretly sent from Malaysia or Singapore. So, in the 1970s and 1980s, they learned everything about China through third parties or neighboring countries. Thus, those who lived in the peripheral areas of Indonesia that were closer to Singapore or Malaysia had more exposure to information on China and Taiwan, and Chinese culture, compared to those living in the central areas such as Java. This situation made Chinese living in different areas in Indonesia have different views on their identities. For example, in Java, many Chinese have "lost" their culture and identity as Chinese. Because of the political situation at that time, they chose to assimilate into the society where they lived, both in terms of identity and in terms of cultural belief. They prefer to choose religions that are not associated with Chinese such as Confucianism and Buddhism. However, the Chinese outside of Java, especially the provinces and cities that have a large number of Chinese, have different perspective. Because of their number and their wide exposure towards Chinese culture, the Chinese living in the areas such as Pontianak, Singkawang, Medan, Batam, and Riau, still practice Chinese traditions and cultures. They still use Chinese dialects in their daily lives. During the New Order regime, when all Chinese customs and culture were forbidden, and Chinese-language publications were banned, Chinese Indonesians in those regions received information about China through Singapore and Malaysia (Interview with Dr. Dato Hendry Jurnawan, July 2017).

According to Professor Wang Gung Wu, if we study the history of Indonesia, especially during the period of the New Order regime (1966-1998), we will find that the history written at that time was politicizing the interests of individuals and strengthening the role of those in power. The Suharto regime which was in power for more than 32 years has affected the lives of the Chinese. Apart from the fact that most Chinese have lost their identity and culture, the role of the Chinese was restricted in the economic sector. Hence, they were regarded as "economic animals." Although Suharto was anti-Chinese, he also realized that the role of the Chinese in Indonesian economy was crucial. If the economy of the Chinese was overthrown, the impact would be the downfall of the national economy. Therefore, in addition to using some of the economic power of the Chinese, the New Order regime also deliberately removed the historical role and contribution of the

\footnotetext{
${ }^{5}$ Liao Zuolian (deceased) was a member of the Kuomintang in Pontianak, West Kalimantan's province. He told the researchers that time if he sent a letter to Taiwanese or Mainland-Chinese friends in the early 1970s, he would first send it to Malaysia. Also, ask friends from Malaysia's side to resend again to Taiwan or Mainland. He also said that if there were Chinese characters on the envelope, the authorities would take a look at them first, and then their envelopes would only be written in Indonesian or English.
} 
Chinese to Indonesia. In this way, the government created "misleading politics," which made it possible for Indonesian nationals to see the Chinese as a "problem." (Interview with Professor Dr. Wang Gung Wu, 25 September 2007). According to the notes of Benny G. Setiono, Sinophobia was often used as the "political ammunition" of the New Order regime. He stressed that every time political turmoil occurred in Indonesia, it often involved violent action against Chinese Indonesian (Setiono, 2003).

In 1989, the relation between Indonesia and China began to get better. President Suharto met with Chinese Foreign Minister Qian Qi Chen when he attended the funeral of emperor Hirohito of Japan in Tokyo, to discuss the relations between two countries. Then from August 6th to 9th, 1990, Chinese Premier Li Peng signed a Diplomatic Memorandum of Understanding with Indonesian Foreign Minister Ali Alatas when he visited Indonesia. In the year before the signing of the restoration of diplomatic relations, Ani Soetjipto, a professor at the University of Indonesia's School of Politics, stated that she believed that Indonesia's Chinese community is diversified. According to her, most of the Indonesian Chinese have left their Chinese identity. When the riots against Chinese in Indonesia occurred, the Chinese were not protected by the Chinese government. Therefore, her views on the Chinese issue are no longer a problem for China (Kompas, 1989).

After the end of the Cold War, Indonesia and China slowly improved their diplomatic relations. However, improvement of diplomatic relations did not mean that the Chinese-Indonesian problem was automatically resolved. The governments of both countries hoped that the signing of a Diplomatic Memorandum of Understanding between the two countries would gradually solve the Chinese-Indonesian issue. However, the 1997 Asian financial turmoil caused the riots in Jakarta in 1998. This riot shows that the Chinese problem has not been resolved yet. Although Suharto's assimilation policy was successful, Indonesian society's hatred towards the Chinese Indonesians made the Chinese rethink about their identity and their position in Indonesia. After the riots, Indonesia became more democratized. Many political parties were established, including those of race-based parties, such as the "Partai Reformasi Tionghoa" (Chinese Reform Party). Chinese cultures were also well accepted. For example, there are Chinese language courses from kindergarten to university. Discussion on things related to China and Chinese peoples and cultures were not as sensitive as it was during the Suharto era. Nevertheless, there have also been many scholars who have studied Overseas Chinese, Chinese culture, and China. However, most of these scholars study from English sources, or they use the Suharto's thinking of China and Chinese Indonesia (Lai Jian Wen, 2016).

Indonesian "indigenous" scholars who do research on China and Chinese issue often have skeptical and judgmental opinions. For example, La Ode, Lecturer at the Indonesian National Defense University, believes that the opening of Chinese Indonesian to elections and the establishment of diplomatic ties with China will cause a return of warming relations between Chinese-Indonesian and the 
"Motherland". So, the opening of Chinese-Indonesian participation in Indonesia's political must be carefully considered (La Ode, 2012). When Chinese Indonesians in different eras are compared, those living in the present era have a common ground with those living in the previous era, that is, there are always two views on China and Chinese identity. The first view regards China as a foreign country. They are mostly culturally localized and educated in Indonesia and/or Western countries. The second category is the one who still regards China as their ancestral land. They think that although they are already Indonesian nationals and must be loyal to Indonesia, their ancestors came from China. In their daily life, they still celebrate Chinese festivals, and they still have close feelings towards China. They are usually educated in Chinese and are the descent of second or third generation in Indonesia or are often referred to as "Totok. "However, the views of these two types of Chinese Indonesian can represent the political and cultural tendencies of some Indonesian Chinese (Fossati, et. al, 2017).

\section{Chinese Indonesian Identity: Are They Indonesian or Chinese?}

When exploring the identity of Chinese Indonesian Chinese, the meaning of identity is usually vague. As far as we know, Indonesia is a multi-ethnic country; there are Javanese, Malays, Sundanese, and hundreds of other indigenous peoples, as well as Indonesians of foreign descent, such as India, Arab, and Chinese. Among Indonesians of foreign descent, the Chinese is unique because they are still divided on which term they use to identify themselves: "Cina," "Tionghoa" or "Chinese." This opinion is based on the result of a questionnaire survey conducted by Chinese researchers in several large Indonesian cities on social media. Most of the ethnic Chinese in Java Island agreed that the name "Cina" should be changed to "Tionghoa." They think that "Cina" is the negative label given to the Chinese in the Suharto era. After the failure of Communist coup in Indonesia, the New Order regime transformed the Indonesian people's antineocolonial movement into an anti-China movement. In March 1967, the Indonesian government unilaterally changed the name of the People's Republic of China (Republik Rakyat Tiongkok) to the Republik Rakyat Cina, and to erase the superior feelings of Chinese Indonesians and elevate the degree feelings of Indonesians who feel inferior (Lai Jian Wen, 2016).

Therefore, for some Chinese Indonesians, the term "Cina" was a form of insult from the New Order regime because Suharto thought that Chinese Indonesian were China's agents of influence, especially after the September 30 incident. However, for the West Kalimantan Chinese, the term "Cina" is straightforward and not have special meaning. The daily Chinese language of this province is Hakka and Chaozhou dialects, which are also spoken by many of the indigenous ethnic groups. The Chinese customs in West Kalimantan are still very strong. They still celebrate Chinese holidays. Older Chinese people read the Chinese newspaper, listen to radio and television programs from Mainland China or Taiwan, along with democratization in Indonesia and lift the discrimination laws against Chinese in Indonesia. Later, the new generation of Chinese Kalimantan chose Taiwan as their 
first choice for learning Chinese. They call themselves "Thong nyin" (Chinese people who are still of natives Chinese blood). For them, the term "Cina" is not discriminative. China is "Cina" in local Malay language. The Chinese and the natives in the area sometimes use "Orang Cin" to call local Chinese. However, because most Chinese Indonesians think that "Cina" has a derogatory meaning, it is necessary to re-introduce the term "Tionghoa" to Indonesian society. After Abdulrahman Wahid took office, he decided to take off "Cina" and changed back to "Tionghoa." (Tan, 2008)

It is evident that Chinese Indonesians' understanding on their "identity" and "China" is a process of finding who they are. Although the Chinese chose Indonesian nationality in Indonesia, did they integrate into Indonesian society? This question appears because Indonesian officials or other ethnic groups often question the Chinese regarding their identity and the natives often link Chinese Indonesians with China. The impact is that the majority of Indonesian society believe that Chinese Indonesians are loyal to China, although many Chinese do not speak Mandarin or any other dialects and they adopt lifestyle and habits of the society where they live. Even some have dissociated themselves from Chinese culture. Therefore, during the Suharto period, the division of the indigenous (Pribumi) and non-indigenous (Non-pribumi) was apparent. If Chinese Indonesians are compared to the Chinese in the Philippines or Thailand, the Chinese Indonesians have not found a form of their own identity yet. The Chinese in Thailand and the Philippines have accepted as local people. However, when Chinese Indonesians face discrimination, they often question themselves "Who Am I?" Which country am I from?" This happens because, unlike other Indonesians of foreign descent, such as the Arabs and the Indians who did not face blatant discrimination, the Chinese feel that they are always connected with China or accused of being "Chinese-oriented." They are often regarded as foreign ethnicity. Of course, all of them living in Indonesia and holding Indonesian citizens cards belong to Indonesian nationals. However, in addition to being labeled as of foreign ethnicity, the Chinese are often referred to as "WNI Keturunan Cina" (Indonesian Chinese descent) or in various places or media (Interview with Professor Dr. Leo Suryadinata, 4-5 December 2007).

All along, official decisions have often victimized and marginalized Chinese people. In fact, most Chinese regardless of their willingness or oppression are trying very hard to break away from their Chinese status. However, the riots that occurred in 1965 and 1998 left the Chinese-Indonesian with a very heavy wound. All their efforts are in vain. This created what so-called identity crisis in the Chinese community. Is it better to be Indonesian or Chinese? Is leaving Indonesia in order to choose the nationality of the third country also an option? According to Dr. Thung Ju Lan, a senior researcher of Indonesian Institute of Sciences, Chinese Indonesians face two choices. They continue to be Indonesian or Chinese. However, the New Order regime gave the Chinese born in Indonesia a choice, namely, complete assimilation (Thung, 1998). However, according to Dr. Thung's 
observation, this policy failed because, on the one hand, the Indonesian government hopes to integrate the Chinese into Indonesian society through assimilation, but the Indonesian society showed suspicion towards them. That is why they are not fully accepted as the members of the society. On the other hand, it is not easy to eliminate a culture from its people. In this case, it is not easy to eliminate Chinese culture from the lives of the Chinese Indonesians.

Relatively speaking, it is not easy for the Chinese to choose to preserve their Chinese identity because Chinese identity has a negative connotation for Indonesian bureaucracy and society. Maintaining the Chinese identity is means that the Chinese should be ready to accept the various forms of discrimination, such as inequality regarding of treatment from all sides. Dr. Thung emphasized that there was a change in the status of "Chinese" in Chinese Indonesian. It means the change from the cultural tradition of traditional Chinese to the modern Chinese in Indonesia. They have regrouped into a new ethnic group. If they still prefer to maintain the culture of "pure Chinese," when the relationship between Indonesia and China deteriorates, they may become the targets of attack. In addition, Dr. Thung also believes that Chinese identities also makes Indonesian society suspicious. When the society cannot stand the oppression of economic and feel helpless to government policies, the first one to be targeted are the Chinese, thus explaining why anti-Chinese riots often occur during the Suharto era (interview with Dr. Thung Ju Lan, 24 August 2016).

Thung believes that since Chinese Indonesians often get "pressure" from various parties and they are also not sure about their own identities, she argues the orientation of Chinese Indonesians can be classified into four categories. The first category is that they will always be Chinese and inherit Chinese culture and customs. The second category is that they are already assimilated and the status of "Chinese" is a "curse." The third category is those who think that they have "transcended" into so-called internationalization. They think that wherever they live, they can be citizens of any country. The fourth category is Chinese who are economically oriented. They avoid mentioning political issues. According to Dr. Thung, Chinese-Indonesian has tried to search many concepts regarding their identities in Indonesia (interview with Thung Ju Lan, 24 August 2016).

Symphony Akelba Christian writes in his article "Identitas Budaya Orang Tionghoa Indonesia" (Cultural Identity of Chinese Indonesian) that culture, history, and the power holder in Indonesia play a significant role in the construction of Chinese Indonesian identity. From a historical and cultural point of view, Chinese Indonesians are not a homogenous group. Their ancestors came from all regions of China. Chinese from the different areas brought different cultures. Therefore, their culture and language are not the same. Because most of the ancestors of Chinese Indonesians came from Guangdong, Fujian, and Hainan, the cultures and languages of Chinese Indonesians are diverse. In other words, although all Chinese, they also have different characteristics, and living habits, communications, and so on are all different. 
The Chinese who have emigrated from China have been migrating to various regions of Indonesia and have been influenced by different local customs of Indonesia. These customs and practices have also become elements of their new identities construction. For example, when two Hokiannese first met, they would ask each other "Where are you from? Bangka, Medan or Kalimantan?" These are all Indonesia's cities, so even if these Chinese are Hokkiannese, living in different towns and provinces has caused them to adopt different customs. Dr. Christian believes that the first generation of Chinese Indonesians strictly followed their traditions. For example, people with the same surname cannot intermarry. However, these cultures have been largely eliminated by the New Order regime after 1967. In particular, after the implementation of the assimilation policy of using Indonesian names, instead of their Chinese names, the Chinese identities have been unrecognizable.

Now, many Chinese Indonesians add their "Chinese surnames" to their children's Indonesian names or behind their names. Dr. Christian believes that because of the "political" fate that shapes the identity of Chinese Indonesians. He pointed out that the class stratification during the Dutch colonial period gave the Chinese Indonesians higher social position than the indigenous Indonesians. After Indonesia's independence, Suharto's policy was made it difficult for Chinese Indonesians to express their own culture freely. He also argues that the Chinese identity has once again appeared in the process of democratization in Indonesia. Since President Wahid eliminated discriminatory regulations, everything related to Chinese culture appears in public. Then, he mentioned that the government had changed the term "Cina" to "Tionghoa". It has greatly influenced the Chinese and has made them believe that the government recognizes their ethnicity. Interestingly, Dr. Christian found the identity of the older Chinese in Indonesia was different from that of the younger generation. The older generation of Chinese will call themselves "overseas Chinese" and the younger generation of Chinese would call themselves "Chinese Indonesian." The younger generation also feels that their identities are very vague, sometimes they believe that the government has not treated the Chinese Indonesian as Indonesia's "indigenous people," and China has not recognized that they are born in Indonesia are belongs to overseas Chinese (Christian, 2017).

Leo Suryadinata believes that the problem of studying Chinese identities in Indonesia lies in the Indonesian government's failure to define the term "race" in independent Indonesia. Therefore, on the issue of Chinese Indonesian, he asked the question "Who is Chinese?" Is it defined by the country or the society or the Chinese themselves? He further explained that the definition of Chinese Indonesian is more fluid than what the official definition proposes. It is usually defined by "ancestors" rather than "cultures." For example, a child born from mixed married between a male Chinese and Indonesian woman generally considered to be of Chinese descent. Therefore, it is difficult to define the so-called "Chinese" identities on this issue. In the beginning, the Chinese in Indonesia were 
divided into Peranakan and Totok. After the 20th century, the new immigrants from China flooded into Java Island, Indonesia's Chinese society has undergone tremendous changes. In particular, those "Peranakan" and "Totok" have created so-called "new Peranakan" and "new Totok" through "intermarriage." After 1965, the changes in Indonesian Chinese society were much clearer. "New Peranakan" became more Indonesian or Indonesianized, and "New Totok" is now probably closer to the Peranakan. "New Totok" still speak Chinese dialects and limited Chinese mandarin, but due to the assimilation policy, they use Indonesian as their primary language (Interview with Dr. Leo Suryadinata, 4-5 December 2007).

Leo Suryadinata also uses culture to discuss Chinese Indonesians. He believes that Chinese Indonesians Chinese who were born during the New Order era can be described as having been "Indonesianized." On the issue of "Peranakan-ization" and "Indonesianization," some scholars believe that there is no so-called "pure" Chinese in Indonesia because most of them have been assimilated. However, Suryadinata believes that only Chinese in Java Island have been assimilated or Indonesianized. The Chinese living outside of Java are not assimilated. Moreover, he argues Chinese-Indonesians are indeed closer to "Indonesianization." Only so far, it is easy to observe in Jakarta that Chinese define their community or themselves based on their status from different provinces and cities. For example, in Jakarta, there are so-called "Cina-Kota," from The North Sumatera, they are so-called "Cina-Medan", etc. Therefore, ethnic and national identities are still related to culture, while the Chinese living in Indonesia are culturally diversified. So, the term of the "Peranakan" and "Totok" is not suitable now for observing the identity of Chinese Indonesian (Interview with Dr. Leo Suryadinata, 4-5 December 2007).

\section{Conclusion}

Before independence, Chinese in Indonesia and Indonesian indigenous elites jointly fought for Indonesia's independence. The New Order Government abolished the history of Indonesia by eliminating the contribution of Chinese-Indonesian. After Indonesia became more democratized, the government began to publicize the Chinese's contribution to Indonesia's independence. Many Chinese Indonesians explored their ancestors' contribution to Indonesian independence through historical discoveries and research.

When scholars researched Chinese Indonesian and China, the issue was always closely related to anti-Chinese and anti-China riots in Indonesia. The reason why there has been several previous riots in Indonesia is the prejudice that Chinese Indonesians do not have loyalty to the country. After Indonesia's independence, even the Sukarno does not deny the Indonesian Chinese's contribution to Indonesia's independence, but he still believes that the Chinese cannot be included as part of the Indonesian nationality. He is more inclined to Chinese as a foreign ethnic group. Therefore, the Chinese were allowed to choose to join Indonesian citizenship or insist on their Chinese nationality. In the era of the Indonesian New 
Order Government, the assimilation policy was adopted. However, this policy also has its contradictions.

Suharto actively implemented assimilation policies. Also, the Indonesian nationals were legally divided into two parts. They were the indigenous (Pribumi) and nonindigenous (non-pribumi). After Suharto stepped down, Indonesia has made several changes and replaced many of the laws and regulations that were unfavorable to Chinese Indonesians. However, the Indonesian society still holds the division between the pribumi and non-pribumi. It can be seen from the latest 2017 election methods and results in Jakarta. During the election campaign in Jakarta, the terms "Cina", "non-Muslim", and non-pribumi were often used to attack Basuki Tjahaja Purnama, the governor of Jakarta at that time.

Therefore, Chinese Indonesians still belong to marginalized ethnic groups. However, seen from the current situation and the result from several riots, the status of the Chinese in Indonesia will be affected by the relationship between Indonesia and China. Concerning the relationship between the Chinese Indonesian and China, how does the Chinese Indonesian understand and explain their identity between Chinese-Indonesia and China? It must depend on the family's background and the person's education to describe it and regarding characters and their views on China. For Peranakan, China is a foreign country. Meanwhile, the second or third generation of Chinese descendants in Indonesia retains the notion that China is their ancestral land, although they recognize their loyalty to Indonesia. Therefore, even after several anti-Chinese riots occurs in Indonesia and China's "coldness" reaction, how do Chinese Indonesian feel about China and their identities? It is complicated. Peranakans admit that they are Indonesian locals, and the "Totok" emphasize and recognize that although they are Indonesians and also Chinese, this is the characteristic of Chinese Indonesian.

\section{References}

\section{$\underline{\text { Books }}$}

Coppel, Charles A. (1994). Tionghoa Indonesia Dalam Krisis [Indonesian Tionghoa in Crisis]. Jakarta: Pustaka Sinar Harapan.

Lai, Jian-Wen. (2016). Yinni dui zhongguo de zhengce lunshu yu dui huaren de shenfen jiangou: 1950-2012 [Indonesia's Policy on China and the Construction of Chinese Identity: 1950-2012]. Taipei: NTU Press.

M. D., La Ode. (2012). Etnis Cina Indonesia Dalam Politik: Politik Etnis Cina Pontianak dan Singkawang di Era Reformasi 1998-2008 [Indonesian Chinese Ethnic in Politics: The Politics of Chinese Ethnic in Pontianak and Singkawang in Reform Era 1998-2008]. Jakarta: Yayasan Pustaka Obor Indonesia.

Gu Chang Yong. (2002). Yinni zhengti zhuanbian [The Political Reform in Indonesia]. Kao-Hsiung: National Sun Yat Sen University Press. 
(2002). Yinni: Zhengzhi jingji yu shehui [Indonesian Political and Socio-Economy]. Kao-Hsiung: Kao-Hsiung Fuwen University Press.

(2005). Pemikiran Politik Etnis Tionghoa Indonesia 1900-2002 [Political Thought of Indonesian Chinese Ethnic 1900-2002]. Jakarta: Pustaka LP3ES Indonesia.

Qiu Zheng Ou. (1965). Huaqiao wenti yanjiu [Overseas Chinese Studies]. Taipei: National Defense Research Institute.

(1995). Su jia nuo shidai yinni pai hua shishi [The Fact of AntiChinese in Sukarno Era]. Taipei: Academy Sinica.

Setiono, Benny G. (2003). Tionghoa Dalam Pusaran Politik [Chinese in the Political Currents]. Jakarta: Elkasa.

Suryadinata, Leo. (1994). Politik Tionghoa Peranakan di Jawa [Politics of Chinese Peranakan in Java]. Jakarta: Pustaka Sinar Harapan.

(2004). Peranakan's Search for National Identity: Biographical

Studies of Seven Indonesian Chinese. Singapore: Marshall Cavendish Academic.

Tan, Melly G. (2008). Etnis Tionghoa di Indonesia-Kumpulan Tulisan [Chinese Ethnic in Indonesia-A Collection of Writing). Jakarta: Yayasan Obor Indonesia.

$\underline{\text { Journals }}$

Christian, Symphony Akelba. 2017. "Identitas Budaya Orang Tionghoa Indonesia [Cultural Identity of Indonesian Chinese People]", Jurnal Cakrawala Mandarin, Asosiasi Program Studi Mandarin Indonesia 1(1): 11-22.

Fossati, et. al. 2017. "The Indonesia National Survey Project: Economy, Society and Politics." Trend in Southeast Asia, ISEAS Publishing: 2017 (10): 1-25.

Schwarz, Adam. 1997. "Indonesia After Suharto." Foreign Affairs 76: 119-134.

Turner, Sarah. 2003. "Speaking Out: Chinese Indonesians after Suharto." Asian Ethnicity 4(3):337-352.

W. F. Wertheim and The Siauw Giap. 1962. "Social Change in Java, 1900-1930." Pacific Affairs, Vol. 35, (3): .223-247.

Newspapers

Kompas. 1966. "Bangsa Indonesia turunan Tionghoa protes keras RRT". Djakarta, 14 April 1966.

Kompas. 1989. "Masalah Etnik Cina dalam Normalisasi Hubungan RI-RRC." Jakarta, 6 Desember 1989. 
Kompas. 2018. "China Terapkan Visa Khusus Untuk Warga Keturunan Tionghoa." Jakarta, 5 Februari, sec. Travel.

Jahja, Junus. 1995. "Partai Tionghoa Indonesia 'Manfaatnya bagi Keturunan Cina' 50 Tahun Indonesia Merdeka." Kompas, 25 Juli.

Ju-Lan, Thung. 1998. "Pengalaman Etnik Cina Dalam Pembentukan Identitas Nasional Indonesia." Simposium Etnis Cina Sebagai Minoritas di Indonesia, 26 Oktober 1998 at Depok, Indonesia.

Sudibyo, Agus. 2001. "Pers Tionghoa, Sensibilitas Budaya, dan Pamali Politik." Kompas, April 1.

Suryowati, Estu. 2017. "Peneliti Senior LIPI: Pilkada DKI Jakarta, Pilkada yang tidak Sehat," https://nasional.kompas.com/read/2017/05/03/18124191/peneliti.senior.lipi.pilk ada.dki.jakarta.pilkada.yang.tidak.sehat Latest update 16 June 2018.

Prasetya, Eko. 2018. "Dari 17.504 Pulau di Indonesia, 16.056 telah diverivikasi PBB," in https://www.merdeka.com/peristiwa/dari-17504-pulau-di-indonesia16056-telah-diverifikasi-pbb.html Latest update 6 June 2018.

Windoro, Adi, Helena F Nababan, Pingkan Elita Dundu. 2016. "Kali Angke, Aliran Kemelut Sejarah Kelam Jayakarta." In https://megapolitan.kompas.com/read/2016/11/28/17000011/kali.angke. aliran. kemelut.sejarah.kelam.jayakarta Latest update 6 June 2018.

THHK. 2013. "Tiong Hoa Hwe Koan." in http://www.jakarta.go.id/web/encyclopedia/detail/3265/Tiong-Hoa-Hwee-Koan. Latest update 16 January 2018.

\section{Interviews}

Interview with Dr. Dato Hendry Jurnawan, July 2017, by The Research \& Educational Centre for Chinese Studies and Cross-Taiwan Strait Relations, Department of Political Science, National Taiwan University, in http://www.chinastudies.taipei/comm2/InterviewIndonesia\%20Hendry\%20Jurnawan\%20anticopy .pdf

Interview with Professor Dr. Leo Suryadinata, 4-5 December 2007, by The Research \& Educational Centre for Chinese Studies and Cross-Taiwan Strait Relations, Department of Political Science, National Taiwan University, in http://www.china-

studies.taipei/comm2/interviewS\%20Leo\%20Suryadinata\%20new.pdf

Interview with Dr. Sunardi Mulia ,2015 ,by The Research \& Educational Centre for Chinese Studies and Cross-Taiwan Strait Relations, Department of Political 
Science, National Taiwan University, in http://www.chinastudies.taipei/comm2/Sunardi\%20Mulia.pdf.

Interview with Dr. Thung Ju-Lan, 24 August 2016, by The Research \& Educational Centre for Chinese Studies and Cross-Taiwan Strait Relations, Department of Political Science, National Taiwan University, in http://www.chinastudies.taipei/comm2/Interview-with-Dr-Thung-Ju-Lan-English\%20anticopy.pdf Latest update 9 January 2019.

Interview with Professor Dr. Wang Gung Wu, by the Department of Political Science of National Taiwan University, The Research and Educational Center For China Studies and Cross Taiwan-Straits Relations, 25 September 2007, in http://www.china-studies.taipei/comm2/InterviewSGungwuW.pdf.

Audiovisual Materials:

New Tang Dynasty Television. (2013). Wei shipin zhongguo xinwen shipin yinni pai hua baoluan 15 nian [The News from New Tang Dynasty Television which discussed 15 years after the May 1998 Riots]. [video file]. Retrieved from https://www.youtube.com/watch?v=TfAjqYIOXtM2018/01/29. 